\title{
THE GENETICAL RELATIONSHIP BETWEEN HEIGHT AND YIELD IN WHEAT
}

\author{
C. N. LAW, J. W. SNAPE and A. J. WORLAND \\ Plant Breeding Institute, Cambridge, England
}

Received 23.v.77

\begin{abstract}
Summary
Apart from a higher proportion of non-additive variation for yield, the analysis of four diverse wheat varieties indicated that the presence and direction of dominance, as well as the incidence of duplicate interactions was similar for both yield per plant and final plant height. The study of $\mathrm{F}_{3}, \mathrm{~F}_{4}$ and $\mathrm{F}_{5}$ lines showed that these two characters were positively correlated. This correlation occurred irrespective of plant spacing. Selection for height was found to be more effective at improving yield than direct selection for yield. The positive correlation between height and yield was observed among a set of intervarietal chromosome substitution lines. At least one chromosome from each homoeologous group was shown to participate in this correlation, suggesting that all the chromosomes of wheat carry genes affecting this relationship.

Although intermating studies provided evidence of " breakable " repulsion linkages between genes for height and yield, the predominant organisation of the genes for these two characters was either " tight" coupling linkages or pleiotropy or both. Because so many genes were evidently involved it is argued that pleiotropy must be the major contributor to the positive relationship between the two characters.

This positive correlation is contrary to the breeders' selection aims of short-straw with high yield, so that the genes responsible will be maintained at intermediate frequencies in breeding populations. It is suggested that a way of utilising their full potential in breeding could be to introduce independently acting genes for dwarfism and then to select for tall, high-yielding plants. This selection for "tall-dwarfs" might be accomplished by using the Norin 10 dwarfing genes, Rht1 and Rht2, which have proved to be so successful in the development of the high-yielding semi-dwarf wheats of the "Green Revolution ".
\end{abstract}

\section{INTRODUCTION}

Tux relationships between height and yield in wheat have interested plant breeders for many years. The early wheats of agriculture, both at the tetraploid (Triticum durum, $2 n=4 x=28$ ) and the hexaploid (Triticum aestivum, $2 n=6 x=42$ ) levels were tall and reached heights of around 150 to $170 \mathrm{~cm}$. Under present day cultivation in which high fertiliser levels are common, such wheats perform poorly because among other weaknesses their tallness makes them very susceptible to lodging. To a lesser, but nevertheless important, extent this was a recurring problem even before artificial fertilisers began to be widely used in agriculture. Breeding objectives as a consequence were strongly influenced by the problem of lodging and short-stemmed wheats were a continuing goal of breeders for a number of years. This aim was further stimulated between the two world wars and very much afterwards by the decline in the use of straw for thatching, animal bedding and other purposes.

Consistent and continuing reductions in height with concurrent increases 
in yield of wheat have been and are being achieved in various parts of the world. In Britain between the 1930's and early 1960's wheat heights fell by about $30 \mathrm{~cm}$, from initial heights in excess of $130 \mathrm{~cm}$. During the same period, yields increased from an average of $19 \mathrm{cwt}$ to $32 \mathrm{cwt}$ per acre (Lupton, 1975). In the United States, similar reductions were achieved, although in some areas significant reductions were not obtained until after the introduction of the major dwarfing genes, Rht1 and Rht2 (Allan, Vogel and Peterson, 1968) from the Japanese variety Norin 10 into the breeding programme of the Pacific North West (Vogel, Allan and Peterson, 1963). Before that period, marked height reductions were not realised in many breeding programmes despite strong selection. Indeed, it was frequently believed that tall wheats had a greater potential for high yields than short wheats and that it was impossible to combine high yields with short straw (Briggle and Vogel, 1968).

The introduction of the dwarfing genes from Norin 10 have been of immense importance throughout the world and were in part responsible for the high-yielding semi-dwarf wheats of the "green revolution". These genes are now being introduced into the traditionally high yielding wheats of Europe and the first semi-dwarf wheats having heights of around $70-80 \mathrm{~cm}$ were released recently in Britain.

Genetical studies of height and yield are numerous. Height, ignoring the major genes for dwarfism, has been shown to be controlled by many genes and each of the 21 chromosomes of hexaploid wheat carries genes affecting this character (Sears, 1954; Kuspira and Unrau, 1957; Law, 1966; Law and Worland, 1973a). Where dominance occurs it is usually towards increasing height and is sometimes associated with duplicate interactions (Law and Worland, 1973b; Snape, Law and Worland, 1977). Where complementary interactions have been observed they are associated with an extreme form of dwarfism referred to as grass-clumps (Hermsen, 1963a; Moore, 1969), in which the plants are not only very short and stunted but frequently fail to flower.

For the determination of yield, many genes have also been implicated and all chromosomes are known to participate (Kuspira and Unrau, 1957; Law, 1966, 1968; Sasaki, Moriyasu, Morris and Schmidt, 1968). As for height, dominance is usually towards increased yield and where epistasis has been detected it is commonly of a duplicate nature (Busch, Lucken and Frohberg, 1971).

Simultaneous investigations of the genetics of both characters are, however, not as frequent. Certainly, instances where attempts to relate the genetic organisation of the two characters are rare. This is surprising in view of the known indirect effects that height can have on final yield. This paper describes a series of experiments in which height and yield have been studied concurrently among a range of wheat genotypes employing both conventional biometrical studies as well as assays on the effects of whole chromosomes in inter-varietal substitution lines.

\section{The Wheat varieties STUdied}

Four wheat varieties, Cappelle-Desprez, Poros, Mara and Besostaya I were used extensively in the experiments to be described. The origins of these varieties are as follows: 
Cappelle-Desprez-a French-bred winter wheat which until recently was the major variety grown in Britain.

Poros-a very tall winter wheat bred in the DDR.

Mara-a semi-dwarf wheat bred in Italy. Although Japanese wheats contributed to its parentage, there is no evidence that the major dwarfing genes of Norin 10 are present in this variety.

Besostaya I-a Russian wheat which until recently was the most extensively grown winter wheat.

These were chosen partly because they represent the "key" varieties of the European Wheat Aneuploid Co-operative (EWAG) (Law, 1968), in which an attempt is being made to develop inter-varietal chromosome substitution lines between them, and partly because they represent an unrelated group of agriculturally successful varieties.

Other varieties used in the development of the inter-varietal chromosome substitution lines studied in this paper were the French varieties Bersée, as the recipient parent, and Hybride du Joncquois, as donor parent.

\section{The EXPERIMENTS}

\section{(i) Experiment 1: The diallel cross}

A $4 \times 4$ diallel crossing programme using the four varieties, CappelleDesprez, Poros, Mara and Besostaya I, was commenced in 1971 and this was extended in subsequent years to include $\mathrm{F}_{1}, \mathrm{~F}_{2}$ and backcross generations for each of the cross combinations. For one of the crosses, CappelleDesprez with Besostaya I, $\mathrm{F}_{3}$ lines were also obtained. Seed from each of these generations was sown in the field in the autumn of 1972 and the heights of individual plants and the grain yield per plot recorded at harvest during the summer of 1973.

A randomised block layout consisting of five replications was used. Within each replicate, plots were composed of 22 plants, grown as two rows of 11 plants each. Distances between rows were $30 \mathrm{~cm}$ and within rows, plants were spaced $10 \mathrm{~cm}$ apart. Each replicate block was made up of 179 plots distributed over the generation as follows:

Parents-five plots for each variety.

$\mathrm{F}_{1}$ hybrids-between two to four plots for each $\mathrm{F}_{1}$ including reciprocals. $\mathrm{F}_{2}$,s-four plots for each hybrid combination and reciprocal.

Backcrosses (Bl and 2)--one plot for each backcross and reciprocal. $\mathrm{F}_{3}$ 's-only for the Cappelle-Desprez with Besostaya I cross. 80 plots-each plot representing different $\mathrm{F}_{3}$ families derived from random $\mathrm{F}_{2}$ plants grown in the field during 1972.

\section{(ii) Experiment 2: The detailed investigation of the cross Cappelle-Despre $z \times$ Besostaya $I$}

Using the seed obtained from the first experiment in 1973 and additional hybrid grain derived from a crossing programme in the glasshouse during 1973, a series of generations from the cross Cappelle-Desprez $\times$ Besostaya I were sown in the field during the autumn of 1973. Again a randomised block design was used consisting of three blocks and involving the same plant spacings as in Experiment I. 
Each block was composed of $250 \mathrm{~F}_{4}$ lines made up 25 groups of 10 families derived from $F_{3}$ plants chosen at random in the earlier experiment, 104 lines comprising duplicate plots for each of $52 \mathrm{~F}_{3}$ families derived from random $F_{2}$ plants in 1973, 76 lines representing 38 families and their duplicates obtained from random Bl plants in 1973, and 34 lines representing 17 families and their duplicates also obtained from random B2 plants in 1973. In addition to the two parental varieties, each represented by five plots per block, the following hybrids were also included in each block.

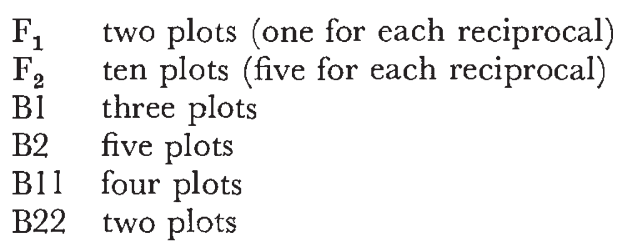

Overall this experiment involved 12 different generations, $P_{1}, P_{2}, F_{1}$, $\mathrm{F}_{2}, \mathrm{~F}_{3}, \mathrm{~F}_{4}, \mathrm{~B}_{1}, \mathrm{~B}_{2}, \mathrm{~B}_{11}, \mathrm{~B}_{22}, \mathrm{~B}_{1 s}, \mathrm{~B}_{2 s}$ from the Cappelle-Desprez $\times$ Besostaya $\mathrm{I}$ cross.

In both Experiments 1 and 2 the height $(\mathrm{cm})$ of each plant was measured and plot yields were obtained and converted into yields per plant.

\section{(iii) Experiment 3: Drilled $F_{5}$ lines of Cappelle-Despre $z \times$ Besostaya $I$}

In order to study the derivatives of this cross under different sowing conditions to the spaced plants of Experiments 1 and 2, $25 F_{4}$ families representing the bulk seed from random $F_{4}$ lines in 1974 were grown in 1975, along with Cappelle-Desprez and Besostaya I as drilled $4.5 \times 1 \cdot 2$ metre plots. Six replications were used.

\section{(iv) Experiment 4: Inter-varietal chromosome substitutions}

This experiment consisted of lines in which single chromosomes in the variety Bersee have been replaced by their homologues from the variety Hybride du Joncquois. These were developed at the Plant Breeding Institute using the Bersee monosomic series and carrying out recurrent backcrosses for four generations using the cytological selection procedures described by Sears (1953) and Law and Worland (1973a).

The substitution lines used in this experiment were grown in 1971 under similar spacings to those used in Experiments 1 and 2. Five replications were employed and measurements of plant height and yield obtained.

\section{(v) Experiment 5: The detailed investigation of the cross Cappelle-Despre $z \times$ Poros}

The $F_{2}, F_{2} \times F_{1}$ (backcross of individual $F_{2}$ plants to the $F_{1}$ ) and $F_{2} \times F_{2}$ (intermated random $\mathrm{F}_{2}$ 's) generations from the cross between the varieties Cappelle-Desprez and Poros were produced to examine whether there is a linkage component of the relationship between height and yield. These generations were developed from crosses involving excess $F_{1}$ and $F_{2}$ grain produced for Experiment 1 and these were crossed in the glasshouse in the summer of 1974.

Twenty random families of the $F_{2} \times F_{1}$ and $F_{2} \times F_{2}$ generations were 
chosen for the experiment and were sown together with the $F_{2}$ in a field experiment sown as a single randomised block in autumn 1975. Seventy plots of the $\mathrm{F}_{2}$ generation were grown together with three plots of each $\mathrm{F}_{2} \times \mathrm{F}_{1}$ family and four plots of each $\mathrm{F}_{2} \times \mathrm{F}_{2}$ family. Each plot consisted of a row of seven plants with a $15-\mathrm{cm}$ spacing between plants and a $30-\mathrm{cm}$ spacing between rows. Five plants were chosen at random from each plot and harvested in the summer of 1975. The heights of these were measured and then each plant individually threshed and grain weights recorded.

For the $\mathrm{F}_{2} \times \mathrm{F}_{1}$ and $\mathrm{F}_{2} \times \mathrm{F}_{2}$ generations, comparisons were made between the sum of the estimates of the within family variance or covariance and the between family variance or covariance.

\section{ThE RESULTS}

(i) Similarities in genetical architecture

The mean heights and yields per plant for Cappelle-Desprez, Mara, Poros and Besostaya $\mathrm{I}$ and their $\mathrm{F}_{1}$ and $\mathrm{F}_{2}$ generations, including reciprocals, for the diallel cross, are given in table 1. The analyses of variance (Hayman, 1954) for these generations are presented in table 2 and indicate that both characters have additive mean squares which are large and highly significant.

TABLE 1

Mean height $(\mathrm{cm})$ and yield per plant $(\mathrm{g})$ for the $F_{1}$ and $F_{2}$ diallel crosses

\begin{tabular}{|c|c|c|c|c|c|c|c|c|}
\hline \multirow{2}{*}{ Yield per nlant } & \multicolumn{4}{|c|}{$F_{1}$ female } & \multicolumn{4}{|c|}{$F_{2}$ female } \\
\hline & Besostaya & $\begin{array}{l}\text { Cappelle- } \\
\text { Desprez }\end{array}$ & Mara & Poros & $\underset{\text { I }}{\text { Besostaya }}$ & $\begin{array}{l}\text { Cappelle- } \\
\text { Desprez }\end{array}$ & Mara & Poros \\
\hline  & $\begin{array}{l}17 \cdot 91 \\
23 \cdot 81 \\
20 \cdot 81 \\
29 \cdot 76\end{array}$ & $\begin{array}{l}21 \cdot 76 \\
23 \cdot 12 \\
18 \cdot 50 \\
25 \cdot 98\end{array}$ & $\begin{array}{l}19 \cdot 98 \\
17 \cdot 86 \\
15 \cdot 54 \\
25 \cdot 99\end{array}$ & $\begin{array}{l}28 \cdot 06 \\
25 \cdot 35 \\
24 \cdot 11 \\
24 \cdot 78\end{array}$ & $\begin{array}{l}17 \cdot 91 \\
21 \cdot 27 \\
16 \cdot 89 \\
24 \cdot 11\end{array}$ & $\begin{array}{l}20 \cdot 25 \\
23 \cdot 12 \\
14 \cdot 23 \\
22 \cdot 89\end{array}$ & $\begin{array}{l}17 \cdot 30 \\
15 \cdot 80 \\
15 \cdot 54 \\
20 \cdot 29\end{array}$ & $\begin{array}{l}24 \cdot 27 \\
25 \cdot 77 \\
20 \cdot 13 \\
24 \cdot 78\end{array}$ \\
\hline Male $\left\{\begin{array}{l}\text { Besostaya I } \\
\text { Cappelle-Desprez } \\
\text { Mara } \\
\text { Poros }\end{array}\right.$ & $\begin{array}{r}89 \cdot 90 \\
99 \cdot 21 \\
90 \cdot 10 \\
118 \cdot 02\end{array}$ & $\begin{array}{r}101 \cdot 96 \\
100 \cdot 12 \\
97 \cdot 19 \\
122 \cdot 39\end{array}$ & $\begin{array}{r}86 \cdot 70 \\
96 \cdot 42 \\
73 \cdot 73 \\
109 \cdot 89\end{array}$ & $\begin{array}{l}116 \cdot 76 \\
123 \cdot 57 \\
113 \cdot 72 \\
132 \cdot 12\end{array}$ & $\begin{array}{r}89.90 \\
97.98 \\
85.08 \\
112.41\end{array}$ & $\begin{array}{r}97 \cdot 49 \\
100 \cdot 12 \\
89 \cdot 71 \\
122 \cdot 49\end{array}$ & $\begin{array}{r}87 \cdot 17 \\
91 \cdot 64 \\
73 \cdot 73 \\
105 \cdot 38\end{array}$ & $\begin{array}{l}112 \cdot 37 \\
122 \cdot 59 \\
105 \cdot 37 \\
132 \cdot 12\end{array}$ \\
\hline
\end{tabular}

However, the $b$ items detecting non-additive effects are a much higher proportion of the total variation in yield than is the case for height in both the $\mathrm{F}_{1}$ and $\mathrm{F}_{2}$ generations.

The study of this $4 \times 4$ diallel cross by the standard procedure of covariance-variance array analysis (Jinks, 1954) also demonstrates the more pronounced non-additive effects of yield compared with height. The relationships between $W r$ and $V r$ for both characters are consistent over blocks and are shown in fig. 1; in every case the slopes of the regression of $W r$ on $V r$ are not significantly different from unity. This implies that an additive-dominance model is sufficient to explain the variations for both characters. The intercept with the $W r$ axis and the position of the points in relation to the limiting parabola indicate that average dominance is almost complete for yield whereas for height dominance is only partial. The nonadditive contribution to variation in height on the basis of this graphical analysis is therefore less than for yield, a conclusion which agrees with the results of the Hayman analysis of variance (loc. cit.). 
TABLE 2

Hayman analysis of variance (19.54) of height and yield per plant for the $\mathrm{F}_{1}$ and $\mathrm{F}_{2}$ diallel crosses

\begin{tabular}{|c|c|c|c|c|c|}
\hline \multirow[b]{2}{*}{ Item } & \multirow[b]{2}{*}{ d.f. } & \multicolumn{2}{|c|}{ Yield per plant } & \multicolumn{2}{|c|}{ Height } \\
\hline & & M.S. $\left(F_{1}\right)$ & M.S. $\left(F_{2}\right)$ & M.S. $\left(F_{1}\right)$ & M.S. $\left(F_{2}\right)$ \\
\hline$a$ & 3 & $268 \cdot 38 * * *$ & $278 \cdot 17 * * *$ & $5941 \cdot 73 * * *$ & $6118 \cdot 79 * * *$ \\
\hline$b$ & 6 & $62 \cdot 41 * * *$ & $23 \cdot 75^{* * *}$ & $149 \cdot 84 * * *$ & $52.89 * * *$ \\
\hline$b_{1}$ & 1 & $149 \cdot 84 * * *$ & 0.05 & $821 \cdot 75^{* * *}$ & $184 \cdot 19 * * *$ \\
\hline$b_{2}$ & 3 & $72 \cdot 21 * * *$ & $42 \cdot 94 * * *$ & $18 \cdot 13 *$ & $9 \cdot 00$ \\
\hline$b_{3}$ & 2 & 3.99 & $6 \cdot 83 *$ & $11 \cdot 40$ & $53 \cdot 07 * *$ \\
\hline$c^{\circ}$ & 3 & $8 \cdot 22$ & 8.99* & $21 \cdot 23^{*}$ & $5 \cdot 23$ \\
\hline$d$ & 3 & 1.87 & $1 \cdot 06$ & 8.90 & 1.73 \\
\hline Blocks & 4 & $25 \cdot 24$ & $24 \cdot 50$ & 115.95 & $129 \cdot 91$ \\
\hline$B \times a$ & 12 & 3.57 & $2 \cdot 48$ & $3 \cdot 69$ & $4 \cdot 37$ \\
\hline$B \times b$ & 24 & $4 \cdot 57$ & $2 \cdot 91$ & $3 \cdot 41$ & $3 \cdot 17$ \\
\hline$B \times b_{1}$ & 4 & $8 \cdot 39$ & $6 \cdot 76$ & $3 \cdot 27$ & $2 \cdot 56$ \\
\hline$B \times b_{2}$ & 12 & 1.09 & $2 \cdot 67$ & 3.97 & $2 \cdot 59$ \\
\hline$B \times b_{3}$ & 8 & $7 \cdot 88$ & $1 \cdot 35$ & $2 \cdot 65$ & $4 \cdot 34$ \\
\hline$B \times C$ & 12 & $6 \cdot 94$ & 2447 & 5.41 & 1.82 \\
\hline$B \times d$ & 12 & $4 \cdot 06$ & $4 \cdot 10$ & $3 \cdot 22$ & $6 \cdot 30$ \\
\hline interactions & & & & & \\
\hline 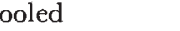 & 60 & $4 \cdot 74$ & 2.97 & $3 \cdot 83$ & $3 \cdot 77$ \\
\hline
\end{tabular}

Also, for both the characters, dominance is towards increasing the magnitude of the character. Thus, for height, $W r+V r$ against the array means is negatively correlated in both the $\mathrm{F}_{1}$ and $\mathrm{F}_{2}$ generations $(r=-0.97$ and $r=-0.74$, respectively) indicating dominance for tallness. A similar relationship is also evident for yield $(r=-0.84$ and $r=-0.37)$.

Apart from Mara, the distribution of the points along the $W r, V r$ regression lines is very similar for both characters in both the $F_{\mathbf{1}}$ and $F_{\mathbf{2}}$ generations. Poros, the tallest and highest yielding variety, carries most of the dominant genes affecting height and yield. Mara, on the other hand, is the shortest and lowest yielding variety, yet only for height does it behave as the most recessive parent, for yield this variety behaves as if it carries more dominant genes than either Cappelle-Desprez or Besostaya I. Mara carries $\mathcal{N} e_{1}$, one of the genes for hybrid necrosis, whereas Cappelle-Desprez carries the complementary gene $\mathcal{N} e_{2}$ (Hermsen, 1963b). The combination and segregation of these genes in the $F_{1}$ and $F_{2}$ generations of the cross between Cappelle-Desprez and Mara was observed to give plants with varying degrees of necrosis so that the mean yield of this cross was depressed. This could account for the apparently anomolous behaviour of Mara in the $\mathrm{Wr}, \mathrm{Vr}$ analysis of yield compared with the similar analysis for height.

In all the other varieties, the distributions of the genes for height and for yield, in terms of their dominance and recessiveness, appear to be correlated, although as has been stated already, there is evidence that the dominance component is larger for yield than for height.

Turning now to the additional information provided by the backcross generations. These permit "scaling tests" to be carried out and the estimates of various genetic parameters to be obtained using the means of the varieties and their $F_{1}, F_{2}$ and backcross generations (Mather and Jinks, 1971). The results of these tests and the genetic estimates by direct fit are presented in tables 3 and 4 for yield and height respectively. Also included are the weighted least squares analysis for each cross in which the parameters 

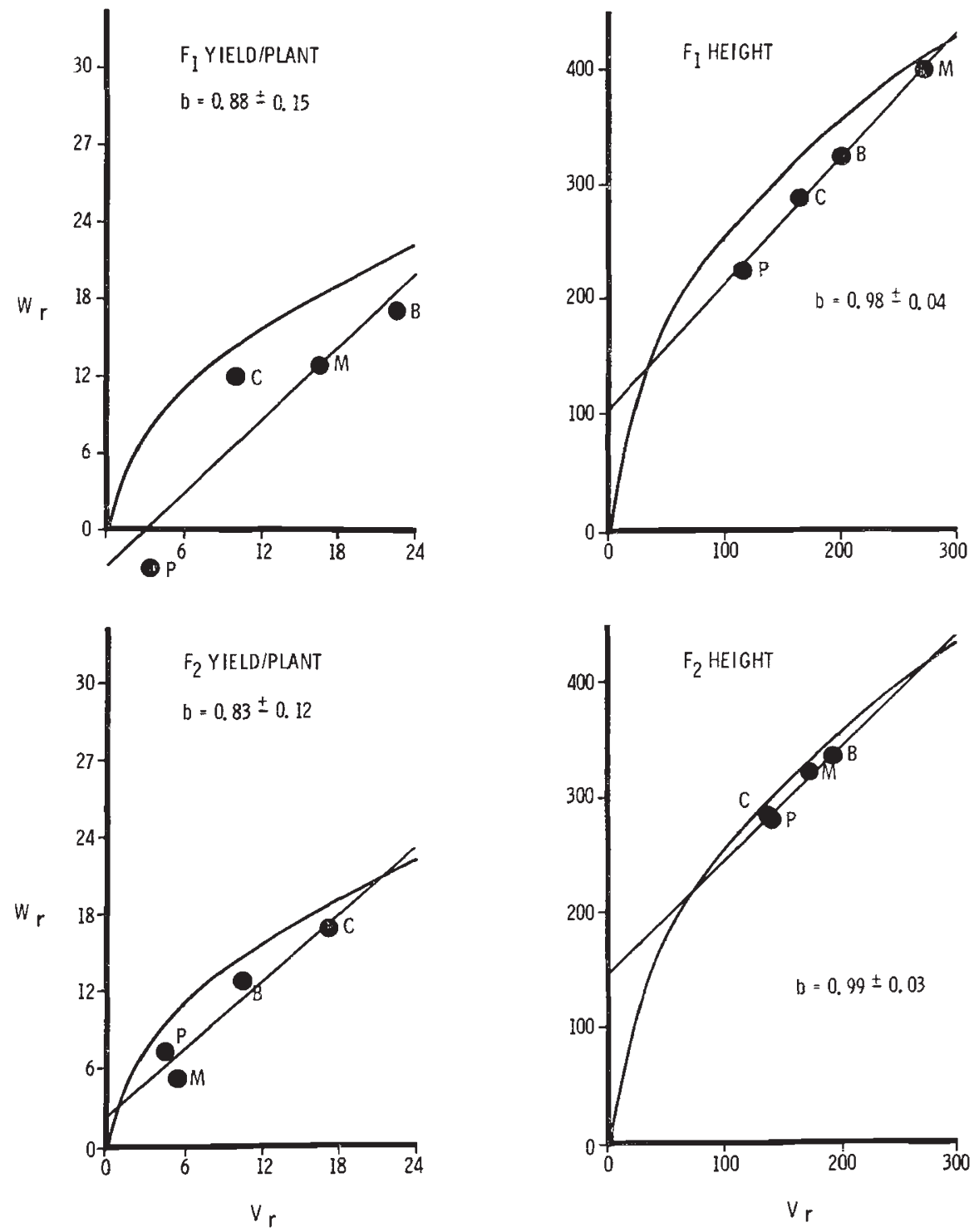

Fig. 1.-The relationship between $W_{\mathrm{r}}$ and $V_{\mathrm{r}}$ for the $F_{1}$ and $F_{2}$ generations for yield per plant and height for the $4 \times 4$ diallel cross. $\mathrm{P}=$ Poros, $\mathrm{B}=$ Besostaya $\mathrm{I}, \mathrm{C}=$ CappelleDesprez and $\mathrm{M}=$ Mara.

$m,[d]$ and $[h]$ have been estimated and tested for "goodness of fit " (Cavalli, 1952; Mather and Jinks, 1971). Apart from the anomolous cross of Mara $\times$ Cappelle-Desprez, four of the crosses give significant individual and jointscaling tests, indicating non-allelic interaction, for both height and yield. The incidence of the significant non-allelic interaction parameters, [i], $[j]$ and [ $l]$, obtained by direct fit also confirm these conclusions. The signs of $[h]$ and $[l]$, the two parameters not subjected to distortion from balanced effects, indicate that the interactions are predominantly of a duplicate 
nature for both characters. Thus, in all cases where $[h]$ and $[l]$ are significant the signs of these two estimates are opposed (Mather, 1967; Jinks and Jones, 1958).

TABLE 3

Scaling tests and estimates of parameters for yield per plant for each of the diallel crosses. Bes = Besostaya I; Cap $=$ Cappelle-Desprez. Test $6=\overline{\mathrm{F}}_{2}-\frac{1}{2} \mathrm{~B}_{1}-\frac{1}{2} \mathrm{~B}_{2}$

$\begin{array}{ccccccc}\text { Test } & \text { Bes } \times \text { Cap } & \text { Bes } \times \text { Mara } & \text { Bes } \times \text { Poros } & \text { Cap } \times \text { Mara } & \text { Cap } \times \text { Poros } & \text { Mara } \times \text { Poros } \\ \text { A } & -1.27 & 1.66 & 0.79 & -3.23^{* *} & -1.09 & -3.01^{*} \\ \text { B } & 0.74 & -0.08 & 1.81 & -3.95^{* * *} & -3.06 * * & -0.72 \\ \text { C } & -1.09 & -1.58^{* *} & 0.90 & -3.50^{* * *} & -0.30 & -2.46^{* *} \\ 6 & -0.82 & -2.37^{* *} & 0.40 & 0.09 & 1.77 & -0.60\end{array}$

Estimates

$\begin{array}{lcccccc}m & 17 \cdot 17 * * * & 7 \cdot 32 * * & 22 \cdot 96 * * * & 19 \cdot 92 * * * & 31 \cdot 23 * * * & 18 \cdot 08 * * * \\ {[d]} & 2 \cdot 77 * * & 0 \cdot 89 * & 3 \cdot 67 * * * & 3 \cdot 67 * * * & 0.89 * & 4 \cdot 57 * * * * \\ {[h]} & 8 \cdot 61 & 26 \cdot 19 * * & -0.64 & -16 \cdot 25 & -20 \cdot 92 & 2 \cdot 01 \\ {[i]} & 3 \cdot 29 & 9 \cdot 48 * * & 1.59 & -0.35 & -7 \cdot 09 & 2 \cdot 40 \\ {[j]} & -4.02 & 3 \cdot 48 & 2 \cdot 04 & 1 \cdot 44 & 3.94 & -4.57 * \\ {[l]} & 12 \cdot 24 & -12 \cdot 63 * & 6.77 & 14 \cdot 71 * & 15 \cdot 40 * * & 5 \cdot 05\end{array}$

Joint test

$\begin{array}{lcccccc}m & \dagger 20 \cdot 22 * * * & 16 \cdot 43 * * * & 21.03 * * * & 18 \cdot 11 * * * & 23 \cdot 56 * * * & 19 \cdot 77 * * * \\ {[d]} & 2 \cdot 41 * * * & 1 \cdot 03^{*} & 3 \cdot 67 * * * & 3 \cdot 81 * * * & 1 \cdot 08 * & 4 \cdot 19 * * * \\ {[h]} & 2 \cdot 74 * * * & 3 \cdot 55 * * * & 7 \cdot 50 * * * & -0 \cdot 96 & 1 \cdot 78 * * & 3 \cdot 67 * * * \\ \chi^{2}(3) & 17 \cdot 62 * * & 11 \cdot 65 * * & 3 \cdot 11 & 39 \cdot 20 * * * & 10 \cdot 80 * & 11 \cdot 42 * *\end{array}$

* $\mathrm{P}=0.05-0.01 ; * *=0.01-0.001 ; * * * \mathrm{P}=>0.001$.

$\dagger$ Joint test for $\chi_{(4)}^{2}$ includes $\bar{F}_{3}$ for this cross.

TABLE 4

Scaling tests and estimates of parameters for height for each of the diallel crosses. Bes = Besostaya I; Cap = CappelleDesprez. Test $6=\overline{\mathrm{F}}_{2}-\frac{1}{2} \overline{\mathrm{B}}_{1}-\frac{1}{2} \overline{\mathrm{B}}_{2}$

\begin{tabular}{|c|c|c|c|c|c|c|}
\hline Test & Bes $\times$ Cap & Bes $\times$ Mara & Bes $\times$ Poros & Cap $\times$ Mara & Cap $\times$ Poros & Mara $\times$ Poro \\
\hline $\begin{array}{l}\text { A } \\
\text { B } \\
\text { C } \\
6\end{array}$ & $\begin{array}{c}3 \cdot 86 * \\
1.30 \\
0 \cdot 07 \\
-2 \cdot 64 *\end{array}$ & $\begin{array}{c}0.90 \\
3.00 * * \\
0.57 \\
-1.38\end{array}$ & $\begin{array}{c}-1.22 \\
0.29 \\
-1 \cdot 86 * \\
-1 \cdot 40\end{array}$ & $\begin{array}{r}0.05 \\
0.52 \\
-1.25 \\
-1.54\end{array}$ & $\begin{array}{l}-2 \cdot 00 \\
-2 \cdot 82 * \\
-3 \cdot 33^{*} \\
-0.88\end{array}$ & $\begin{array}{c}-7.02 * \\
0.97 \\
-2 \cdot 19 * \\
0.84\end{array}$ \\
\hline $\begin{array}{c}\text { Estima } \\
m \\
{[d]} \\
{[h]} \\
{[i]} \\
{[j]} \\
{[l]}\end{array}$ & $\begin{array}{c}84 \cdot 47 * * * \\
5 \cdot 11 * * \\
36 \cdot 96 * \\
10 \cdot 54 \\
5 \cdot 12 \\
-20 \cdot 84^{*}\end{array}$ & $\begin{array}{c}76 \cdot 38 * * * \\
8 \cdot 09 * * * \\
27 \cdot 00^{*} \\
5 \cdot 44 \\
-4 \cdot 21 \\
-14 \cdot 97 *\end{array}$ & $\begin{array}{c}105 \cdot 43^{* * *} \\
21 \cdot 11 * * \\
15 \cdot 68 \\
5 \cdot 58 \\
-3 \cdot 00 \\
-3 \cdot 72\end{array}$ & $\begin{array}{c}80 \cdot 77 * * * \\
13 \cdot 20 * * * \\
23.62 \\
6 \cdot 16 \\
-0.95 \\
-7 \cdot 57\end{array}$ & $\begin{array}{c}112 \cdot 62 * * * \\
16 \cdot 00 * * * \\
4 \cdot 12 \\
3 \cdot 51 \\
-1 \cdot 46 \\
6 \cdot 32\end{array}$ & $\begin{array}{c}106 \cdot 29 * * * \\
29 \cdot 20 * * * \\
-9 \cdot 15 \\
-3 \cdot 36 \\
-15 \cdot 99 * \\
14 \cdot 67\end{array}$ \\
\hline \multicolumn{7}{|c|}{ Joint test } \\
\hline $\begin{array}{l}m \\
{[d]} \\
{[h]} \\
\chi_{(3)}^{2}\end{array}$ & $\begin{array}{r}\dagger 95 \cdot 44 * * * \\
5.33 * * * \\
5.51 * * * \\
13.72 * *\end{array}$ & $\begin{array}{c}82 \cdot 79 * * * \\
7 \cdot 77 * * * \\
7 \cdot 55^{* * *} \\
6 \cdot 96 *\end{array}$ & $\begin{array}{c}110 \cdot 50 * * * \\
20 \cdot 78 * * * \\
6.47 * * * \\
4.87\end{array}$ & $\begin{array}{c}86 \cdot 73 * * * \\
13 \cdot 21 * * * \\
9 \cdot 80 * * * \\
2 \cdot 36\end{array}$ & $\begin{array}{c}115 \cdot 62 * * * \\
16 \cdot 00 * * * \\
6 \cdot 27 * * * \\
9 \cdot 48 *\end{array}$ & $\begin{array}{r}102 \cdot 61 * * * \\
28 \cdot 66 * * * \\
8 \cdot 98 * * * \\
11 \cdot 61 * *\end{array}$ \\
\hline
\end{tabular}

$* \mathrm{P}=0.05-0.01 ; * * \mathrm{P}=0.01-0.001 ; * * * \mathrm{P}=>0.001$.

$\dagger$ Joint test for $\chi_{(4)}^{2}$ includes $\bar{F}_{3}$ in this cross. 
The occurrence of duplicate interactions affecting both characters provides further evidence of the similar genetical architectures for height and yield. It also explains the failure of the earlier $\mathrm{Wr}, \mathrm{Vr}$ analysis to detect non-allelic interactions since this analysis is particularly insensitive to the presence of duplicate interactions (Jinks, 1956; Mather, 1967).

The most detailed investigation of generation means was carried out for the cross of Cappelle-Desprez and Besostaya I. In 1973, the $\mathrm{F}_{3}$ generation was included for this cross only and in 197412 different generations of this cross were studied for both characters. Weighted estimates of $m,[d]$ and $[h]$ were obtained and these are given in table 5. Only yield per plant in 1974 gave a good fit with an additive-dominance model. For height in both 1973 and 1974 and yield in 1973, the addition of the non-allelic interaction parameters $[i],[j]$ and $[l]$ to the model gave a satisfactory explanation of the observations.

TABLE 5

Estimates of the genetic components of the generation means of the cross of Cappelle-Desprez with Besostaya I for height and yield per plant for 1973 and 1974

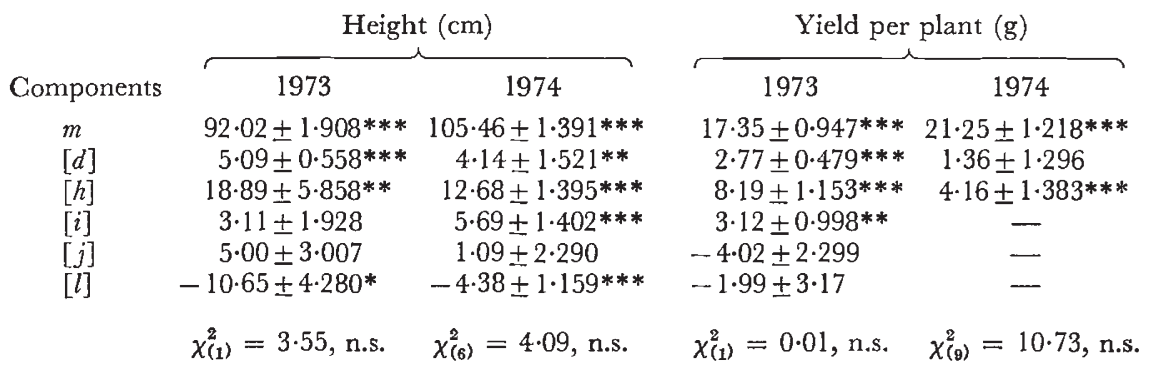

Clearly the estimates for height in both years show $[h]>[d]$ and positive, whereas $[l]$ is negative, indicating apparent overdominance for increased height and duplicate interactions. For yield per plant, $[h]$ is also $>[d]$ and is positive in both 1973 and 1974, whereas [l] is negative but not significant in 1973. This analysis therefore indicates not only that the direction of dominance and the presence of duplicate interactions are the same for both characters but the summed estimates of the genetical components are very similar.

\section{(ii) Genetical correlation between the characters}

The similarities between the genetical effects of height and yield determined from the study of the generation means need not necessarily indicate that the two characters are genetically correlated. To establish whether this is so, it is necessary to study the relationships between segregating lines. Accordingly, the mean measurements for height and yield per plant of the $80 \mathrm{~F}_{3}$ families of the cross of Cappelle-Desprez with Besostaya I in 1973 are plotted against each other in fig. 2. Here a positive genetical correlation between the two characters is very marked $(r=0.77 \pm 0.07, \mathrm{P}<0.001)$. The distribution obtained also establishes the dispersed nature of the genes affecting these two characters in this cross since $F_{3}$ lines transgressing both 
parents are very evident. The apparent overdominance, $[h]>[d]$, obtained from the analysis of generation means of this cross is thus a consequence of dispersed genes and directional dominance for both characters. This positive correlation was also found for $F_{3}$ and $F_{4}$ lines grown in 1974 . The correlation coefficients obtained are given in table 6 along with those for the $1973 \mathrm{~F}_{3}$ family means on to their related $\mathrm{F}_{4}$ group means for various combinations of the two characters. These were also significantly correlated, the

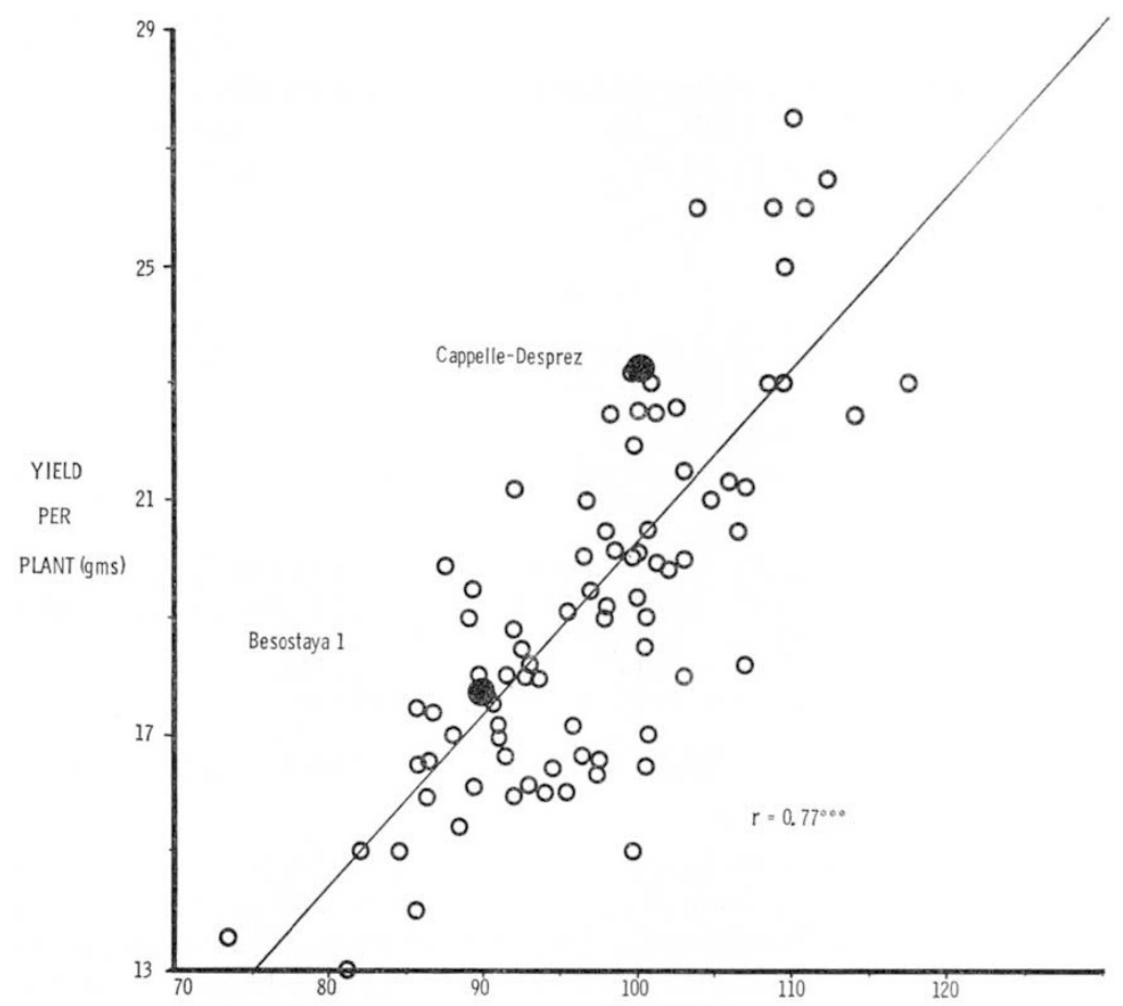

FIG. 2.-The relationship between yield per plant and height of $F_{3}$ lines from the cross of Cappelle-Desprez with Besostaya I.

relationship between the heights of the two generations being highly correlated. The lower correlations between height and yield obtained in 1974 compared with that of 1973 may be due to genotype-environment interactions reducing variation for height and yield in 1974 compared with 1973 (see table 5).

All these investigations were carried out on spaced plants, as well as under conditions in which competition between neighbouring plots might be expected. Such effects might increase the yield and heights of plots having genotypically " tall " plants compared with " shorter" neighbours. To test for this possibility, seed from randomly chosen $F_{4}$ families were sown as bulked $\mathbf{F}_{5}$ lines in 1975 at normal sowing rates and in plots sufficiently large and distributed in such a way as to make competitive effects unlikely. 
The results of this yield trial again showed a positive correlation $(r=0 \cdot 49 \pm 0 \cdot 18, \mathrm{P} \quad 0 \cdot 02-0 \cdot 01)$ between the two characters. Moreover, as is indicated in table 6 , positive correlations are found between the heights and yields of related lines in the $\mathrm{F}_{3}$ and $\mathrm{F}_{4}$ generations with their descendents in the drilled $F_{5}$ generation. Thus, competitive effects and different plant spacings can be ignored as major contributors to the variation observed in these experiments. The genetic variation observed in 1973 and 1974 with spaced plants is a good indicator of the variation expressed under normal sowing conditions.

TABLE 6

Correlation coefficients between mean heights and yields per plant of families from the $F_{3}, F_{4}$ and $F_{5}$ generations of the cross of Cappelle-Desprez with Besostaya I grown in 1973,1974 and 1975

Correlations between generations under spaced plant conditions

$\mathrm{F}_{3}$ height (73) v. $\mathrm{F}_{3}$ yield (73)

$\mathrm{F}_{3}$ height (74) v. $\mathrm{F}_{3}$ yield (74)

$0.77 \pm 0.07 * * *$

$\mathrm{F}_{4}$ height (74) v. $\mathrm{F}_{4}$ yield (74)

$\mathrm{F}_{3}$ height (73) v. $\mathrm{F}_{4}$ yield (74)

$\mathrm{F}_{3}$ yield (73) v. $\mathrm{F}_{4}$ yield (74)

$\mathrm{F}_{3}$ height (73) v. $\mathrm{F}_{4}$ height (74)

$0 \cdot 48 \pm 0 \cdot 07 * * *$

$0 \cdot 45 \pm 0 \cdot 18 *$

$0 \cdot 59 \pm 0 \cdot 17^{*}$

$0 \cdot 76 \pm 0 \cdot 14 *$

$0 \cdot 95 \pm 0 \cdot 06 * * *$

Correlations with $F_{5}$ under drilled conditions

$\mathrm{F}_{5}$ height (75) v. $\mathrm{F}_{5}$ yield (75) $0.49 \pm 0 \cdot 18^{*}$

$\mathrm{F}_{4}$ height (74) v. $\mathrm{F}_{5}$ yield (75) $0.59 \pm 0 \cdot 17 *$

$\mathrm{F}_{3}$ height (73) v. $\mathrm{F}_{5}$ yield (75) $0.50 \pm 0 \cdot 19 *$

$\mathrm{F}_{4}$ height (74) v. $\mathrm{F}_{5}$ height (75) $0.93 \pm 0.08 * * *$

$* \mathrm{P}=0.05-0.01 ; * * \mathrm{P}=0.01-0.001 ; * * * \mathrm{P}=>0.001$.

In a number of cases, the correlations between the yields of different generations is greater than when height is used as a predictor of yield performance. Different genes affecting height and yield as well as different degrees of dominance for the two characters could explain this. However, the different levels of correlation could have important consequences on selection procedures. Because both height and yield in early generations are correlated with yield in later generations, then one or other of these characters will be the more efficient at selecting for yield. In this respect, it would seem from the correlations given in table 6 that selection for yield should be the more effective. On the other hand, it should be noted that all these correlations are based upon the relationships between the means of families and not individual plants. It is possible that height may be the more effective character for yield selections where individual plant data are being considered. This would of course be particularly relevant to selection in the $F_{2}$ where the low heritabilities commonly found for yield per plant makes this generation less promising for yield selection than later generations (Lupton and Whitehouse, 1957).

By using the yield and height values of the $80 \mathrm{~F}_{2}$ plants of the CappelleDesprez/Besostaya $I$ cross which gave rise to the $F_{3}$ families in 1973 , the correlated response when $\mathrm{F}_{2}$ plants are selected for height can be compared with the response when yield itself is used (Falconer, 1961). The response 
to selection for yield in the $F_{2}$ for a given intensity of selection $(i)$ is obtained from:

$$
\mathrm{R} \text { yield }=\frac{\operatorname{Cov} \bar{F}^{3} \text { yield } . \mathrm{F}^{2} \text { yield }}{\left(\text { var } \mathrm{F}_{2} \text { yield }\right)^{\frac{1}{2}}} \cdot i=\frac{10 \cdot 6636 i}{8 \cdot 0265}=1 \cdot 3285 i
$$

whereas the correlated response-following selection for height in the $F_{2}$ is given by:

$$
\mathrm{CR} \text { yield }=\frac{\operatorname{Cov} \bar{F}^{3} \text { yield. } \mathrm{F}^{2} \text { height }}{\left(\operatorname{var} \mathrm{F}_{2} \text { height }\right)^{\frac{1}{2}}} \cdot i=\frac{17 \cdot 1229 i}{9 \cdot 1617}=1 \cdot 8690 i
$$

Clearly, selection for height rather than yield in the $\mathrm{F}_{2}$ achieves higher yield responses in the $F_{3}$.

\section{(iii) Chromosome substitution lines}

It is likely that many genes are responsible for the correlation between height and yield. An estimate of the minimal number of genes that might be involved should be forthcoming from the study of inter-varietal chromosome substitution lines. Law and Worland (1973b) demonstrated a positive correlation between chromosomal effects on height and grain size among the substitution lines of Hope into Chinese Spring. At least eight chromosomes were involved, but total yield was not considered.

Accordingly a set of inter-varietal chromosome substitution lines were studied in which the varieties Bersée and Hybride du Joncquois were used as the recipient and donor parents respectively. These are lines in which single pairs of chromosomes have been replaced by their homologues from the variety Hybride du Joncquois.

The results of substituting these chromosomes into Bersée are shown in fig. 3 where the height and yield figures for each of the 18 available lines are

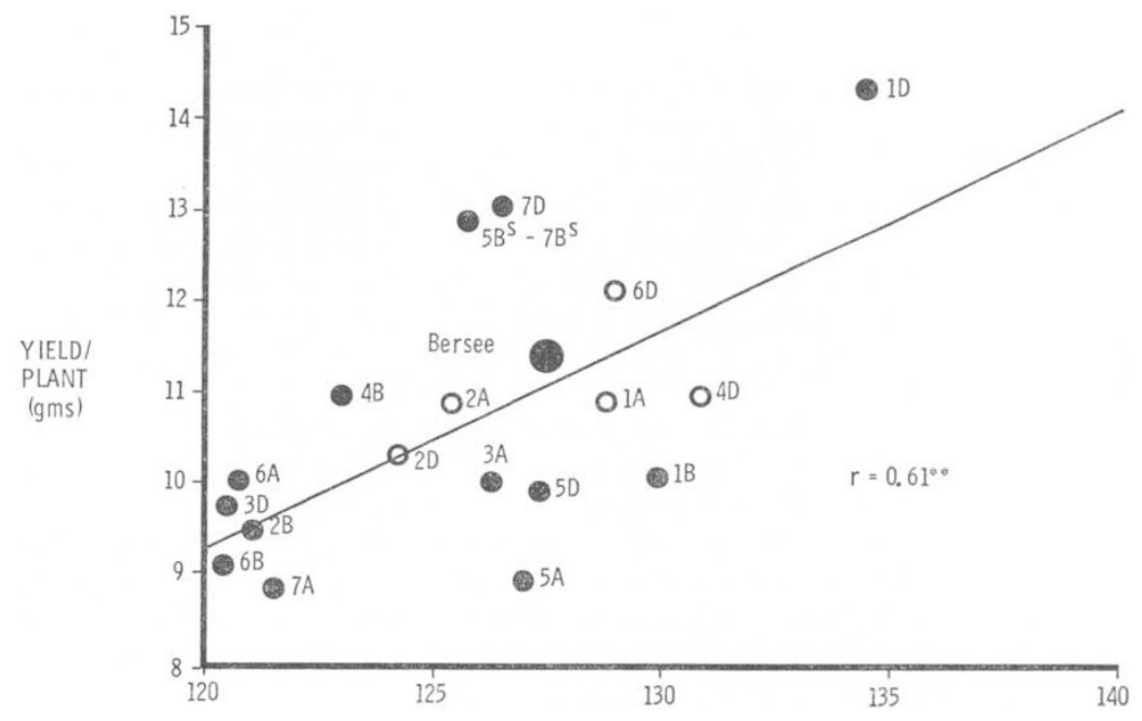

FIG. 3.-The relationship between yield per plant and height for 18 of the chromosome substitution lines of Hybride du Joncquois into Bersée. The closed circles refer to those lines which are significantly different from Bersee in one or both of the characters. 
plotted against each other. Several lines were significantly different from the recipient variety Bersée in both height and yield, but of much greater interest, the two characters were positively correlated. Thus, the genetical association between these two characters is related to the segregation of whole chromosomes and, furthermore, it is evident that many chromosomes are involved. Indeed, at least one chromosome from each of the seven homoeologous groups of wheat exhibits variation in these characters suggesting, as has been established already for each of the characters studied separately (loc. cit.), that all the chromosomes carry genes involved in this relationship.

This study of chromosomal effects also confirms the results of the conventional genetical studies and further underlines the widespread nature of this genetical correlation.

\section{(iv) Linkage or pleiotropy}

It is important to understand the true genetic nature of the correlations observed between height and yield. Genetically these correlations can arise either from positive pleiotropic action of genes on both characters, or alternatively, coupling linkages between genes affecting each character independently. Although it is theoretically possible to study linkage/ pleiotropy from the study of $F_{3}, F_{4}$ and $F_{5}$ generations (Mather and Jinks, 1971), individual plant data are required and these were not available for yield in the experiments so far described.

Now, the study of three generations, the $F_{2}, F_{2} \times F_{1}$ and random intermating of the $F_{2}$ permits " breakable" linkages to be detected unambiguously (Van der Veen, 1959; Perkins and Jinks, 1970). In the absence of linkage between genes affecting a character, the expectations of the genetic variances for each of these generations will be the same. In the presence of linkage, however, the variances will differ. Furthermore, the rank order of the variances over the three generations will indicate the predominant linkage phase. Thus, if the variances of the $\mathrm{F}_{2}>\mathrm{F}_{2} \times \mathrm{F}_{1}>\mathrm{F}_{2} \times \mathrm{F}_{2}$ then the linked genes are on average in coupling, whereas the reverse ranking indicates a repulsion situation.

These relationships also apply if the genetic covariances between characters are determined. With independence of the genes affecting each of the characters, the covariances will not be significantly different from zero; with tight linkage the covariances will also be the same but will depart from zero; with "breakable" linkages between two sets of genes then the covariances will differ and their rank ordering over generations will indicate the predominant linkage phase.

The variances and covariances for height and yield were determined for the $F_{2}, F_{2} \times F_{1}$ and $F_{2} \times F_{2}$ generations of the cross of Cappelle-Desprez with Poros (Experiment 5) and these statistics are given in table 7. Although the variances for height and yield are homogeneous $\left(\chi_{(2)}^{2}=1.31\right.$ and 1.64 , for height and yield respectively), their rankings for both characters suggest that "breakable" coupling linkages may be involved. For the covariances, the values obtained indicate that the two characters are positively associated whereas, and rather surprisingly, the ranking of the covariances is suggestive of " breakable" linkages being predominantly in the repulsion phase, the reverse of the situation suggested for the genes affecting each of the characters sepa rately.

$$
40 / 1-\mathrm{k}
$$


TABLE 7

Variances and covariances for height and yield per plant for the three generations, $F_{2}, F_{2} \times F_{1}$ and $F_{2} \times F_{2}$, of the cross of Cappelle-Desprez with Poros

$\begin{array}{ccccc}\text { Generation } & V \text { height } & \begin{array}{c}V \text { yield } \\ \text { per plant }\end{array} & W H t / \text { yield } & \begin{array}{c}\text { Number of } \\ \text { plants }\end{array} \\ \mathrm{F}_{2} & 78.57 & 80 \cdot 78 & 21 \cdot 65 & 280 \\ \mathrm{~F}_{2} \times \mathrm{F}_{1} & 72 \cdot 4 \mathrm{l} & 78 \cdot 62 & 23.37 & 259 \\ \mathrm{~F}_{2} \times \mathrm{F}_{2} & 69.02 & 70.40 & 29.05 & 339\end{array}$

The genetic analysis of height and yield for this cross and its derivatives in 1973 indicated that the genes for increasing height were concentrated in the variety Poros. This associated gene distribution for height is confirmed in fig. 4 which clearly demonstrates that the heights of the extreme $F_{3}$ families from this cross are very similar to the heights of Cappelle-Desprez and Poros. For the genes for yield, on the other hand, the evidence points to a partly dispersed situation between the parental varieties. Thus, the $[h]$ estimates are larger than $[d]$ for yield but not for height for this cross in 1973. Likewise, in fig. 4, although the yield of Poros is likely to be an underestimate, because of the high level of yellow rust (Puccinia striiformis) infection on this variety in 1975 compared with 1973, the distribution of the $\mathrm{F}_{3}$ lines for yield clearly transgresses both parental varieties.

Associated genes for height and dispersed genes for yield can only be distributed over linkage groups, if repulsion linkages between the two sets of genes are to be found. The evidence for " breakable " repulsion linkages, based upon differences in covariances over generations is therefore consistent with this expectation. However, the association between height and yield among the segregating generations of this cross is strongly positive as is

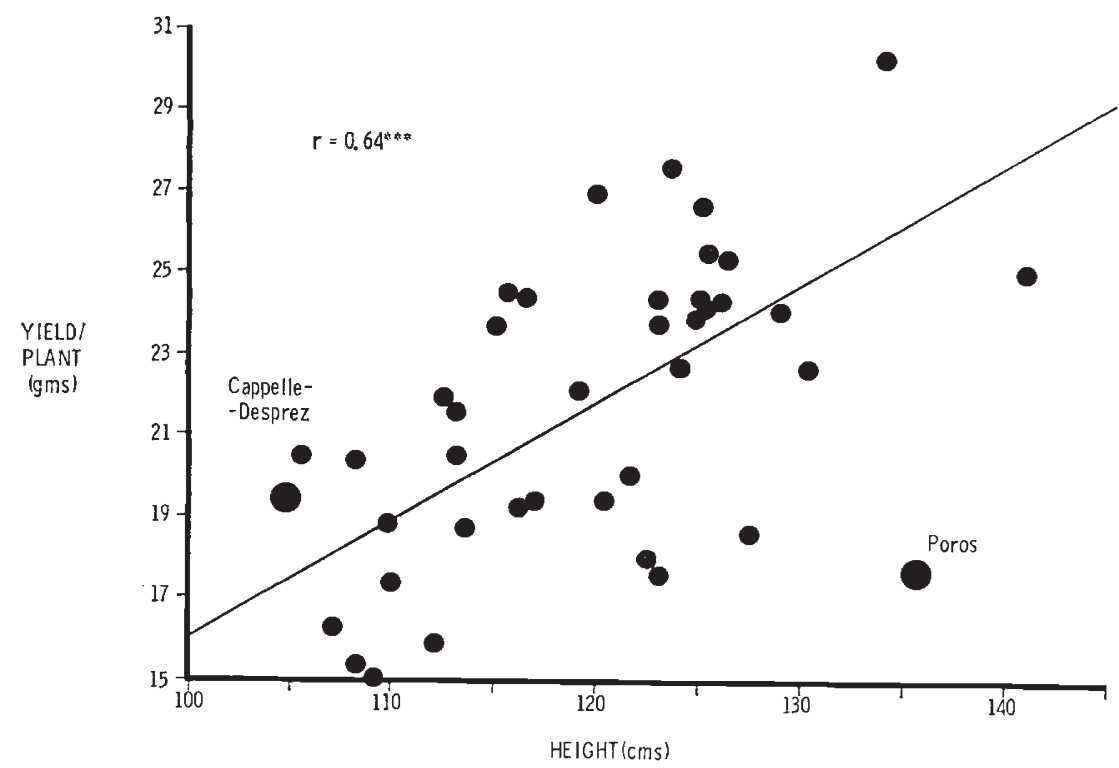

Fig. 4. - The relationship between yield per plant and height of $F_{3}$ lines from the cross of Cappelle-Desprez with Poros. 
clearly shown in fig. 4 for the $F_{3}$ family means and from the positive covariances for the three generations, $F_{2}, F_{2} \times F_{1}$ and $F_{2} \times F_{2}$. This is the opposite of that expected for repulsion linkages and must mean that the predominant organisation of the genes affecting height and yield in this cross must either be one of tight linkages between two sets of genes for increasing height and for increasing yield or a single set of genes acting pleiotropically on both characters positively or some combination of both types of genetic organisation.

It is impossible to prove that pleiotropic effects could be wholly or in part responsible for this positive correlation. However, the evidence from the inter-varietal chromosome substitution lines of Bersée, as well as the range of segregants obtained in the $F_{3}, F_{4}$ and $F_{5}$ generations of Cappelle-Desprez with Besostaya $\mathrm{I}$ and the $\mathrm{F}_{3}$ of Cappelle-Desprez with Poros, indicate that many genes must be involved in determining this positive association. Under these circumstances, it is difficult to see how so many tight, coupling linkages could all have been assembled as a result of selection in the past. A pleiotropic component of this positive relationship would seem therefore to be very likely.

It is also worth commenting further about the repulsion linkages that have been identified in this cross. It is possible that some of the dispersed genes recognised in the analysis of Cappelle-Desprez and Poros are in fact yield genes only in so far as they influence yellow rust resistance. As mentioned, Poros is a highly susceptible variety compared with CappelleDesprez so that this could account for some of the "breakable" repulsion linkages between genes for height and yield. Unfortunately, this intriguing possibility could not be tested, since in the absence of yellow-rust scores, no means were available of distinguishing a gene affecting yellow-rust resistance and thereby yield from any other gene concerned with controlling this complex character.

\section{Discussion}

The evidence from the Cappelle-Desprez and Poros cross demonstrates that a major component of the genetical control of height also influences yield. This relationship is possibly pleiotropic and is positive. Over and above this effect on yield are other genes influencing both yield and height separately. Where linkage between these genes has been established, the predominant phase is one of repulsion. Similar conclusions can also be made for the other cross combinations that have been studied. Based upon the correlation coefficients of $\mathrm{F}_{3}$ and later generations between 20 to 50 per cent of the variation in yield can be accounted for in terms of positively correlated height variation. Also these values are likely to be underestimates since the repulsion linkages between the genes for height and yield would be in opposition to this association between the two characters.

This positive correlation is not confined solely to the work reported here. It is a frequently observed correlation in wheat (Utz, Alber, Schnell and Snoy, 1973; Chaudhry, 1973; Knott and Kumar, 1975), in barley (Riggs and Hayter, 1975), in oats (Sampson, 1971; Rosielle and Frey, 1975), and in sorghum (Casady, 1965; Campbell, Casady and Cook, 1975). It thus appears to be general to many of the cereals used by man.

This generality must indicate that the mechanisms underlying this 
correlation are basic to the growth pattern and physiology of cereal plants. Tall plants would tend to have a greater "biomass" than short plants and the amount of "biomass" might be expected to be correlated with productive potential and final yields. In terms of the "source-sink" relationship of the physiologists (Evans and Wardlaw, 1976), the tall wheats would tend to provide a greater "source" than the short wheats.

Whatever the mechanisms may be, it must be re-emphasised that this correlation does not explain all the variation in yield. There are other genetic causes of increased yield exploited in the production of high-yielding varieties. Nevertheless, the variation in yield attributable to variation in height is likely to have a major influence on any breeding programme. It is therefore necessary to consider the consequences that this type of genetic organisation might have had and is having on the realisation of breeding objectives.

Selection in wheat has been and continues to be towards increased yields combined with shorter straw lengths. This ideotype has been created in order to overcome the lodging weaknesses of tall, high-yielding wheats. These selection aims are in opposition to the observed positive genetic relationship between height and yield. Selection for increased yield would tend to have a positive correlated effect on height, whereas selection for reduced height would tend to depress yields. Inevitably, given such selection pressures and such a genetic organisation, the highest yielding and acceptable varieties will be of intermediate height. In other words not too short for the adverse correlated effects on yield to be significant and not too tall for lodging to occur. Indeed, this model, until the introduction of the major dwarfing genes, Rht1 and Rht2, from Norin 10 in the 1960's (Vogel et al., loc. cit.), was universal amongst successful wheat varieties. Selection for intermediate height varieties would ensure that variation among the genes involved in the correlation between height and yield would be maintained in the breeding population and such genes would tend to bedispersed amongst potential parents. This would account for the widespread reports of this positive correlation.

Such selection might account for the absence of tightly linked or pleiotropically acting genes having negatively correlated effects on these two characters, since such genes would have rapidly become fixed within the breeding population. It could also explain the "breakable" repulsion linkages between genes for height and yield found in the Cappelle-Desprez/ Poros cross.

However, one consequence of the adverse positively correlated effects is that the maximum yield contributions from the genes involved is unlikely to be realised given a continuing selection for short-straw. To exploit fully the increased yields that these genes can produce, lodging resistance might be achieved in other ways than through genes for reduced height. There would then be no restriction to selection for a taller and high yielding ideotype. Alternatively, genes for short straw might be found which have minimal or indeed desirable effects on yield without influencing the expression of the yield-height genes.

It may be that the dwarfing genes, Rht 1 and $R h t 2$ fall into this latter category and some of their success results from their ability to remove the limitations to the exploitation of these correlated effects. If this were to prove to be the case then a strategy for breeding high yielding, lodging 
resistant wheats would present itself. First, to introduce and fix these dwarfing genes very early on in a breeding programme whilst maintaining genetic variation within the population. Secondly, to select strongly not for reduced height, the practice often encouraged by those favouring the concept of harvest index (Donald and Hamblin, 1976), but for increased height. In this way, the positive genetical relationship between height and yield could be exploited fully. The alternative of selecting for even shorter wheats would result in lower yields and what is perhaps more disastrous the loss of allelic variation among the genes for increasing yield and height from the breeding population.

For the reasons mentioned earlier, this method of breeding for " talldwarfs" should not be based upon selection for height alone, but must be carried out in conjunction with positive selection for yield and yield components. However, a major advantage of the selection for height is its ease of measurement and its relative insensitivity to environmental variation. The increased efficiency of selecting for yield via height rather than yield itself has already been mentioned for the $F_{2}$ and $F_{3}$ generations in the Cappelle-Desprez/Besostaya I cross. Similar advantages will also occur in later generations.

A test of the "tall-dwarf" model will require a study of the yield performance of lines segregating for the dwarfing genes. In this way, the influence of these genes on yield can be determined as well as the relationship between height and yield within each of the sub-populations differentiated by the alleles for dwarfing. For the "tall-dwarf" model to work, this relationship should be positive.

It has frequently been asserted that the desirable features of the semidwarf wheats, apart from their shortness, are increased tillering capacity and higher grain numbers (Borlaug, 1968; Bingham, 1972). Such assertions are based upon varietal differences and as a consequence need not relate to the effects of the $R h t$ genes themselves. However, the ability to identify Rht 1 and Rht 2 by their lack of responsiveness to gibberellic acid (Gale, Law and Worland, 1975; Gale and Marshall, 1976) has permitted an accurate classification of segregating lines. Recent studies of these classified derivatives have shown that the $R h t$ genes do indeed influence positively some of the yield components, notably grain number per ear, and that the relationship between height and yield within the populations of $R h t$ and rht homozygotes is still positive (Gale and Law, 1977). Although these results require further corroborative evidence, mainly relating to the behaviour of the $R h t$ genes in different genetic backgrounds and under different growing conditions, it would appear that the conditions for the success of the "tall-dwarf" model are close to being established.

Other evidence also suggests that "tall-dwarfs" are higher yielders than "short-dwarfs". Among the Rht2 semi-dwarf wheats developed in Britain, the highest yielding varieties such as Maris ${ }^{\circledR}$ Hobbit are at the taller end of the semi-dwarf range. Also, amongst semi-dwarf lines of Triticum durum, a positive correlation between height and yield was reported by Joppa (1973); in a dwarf winter wheat programme Stoskopf and Fairey (1975) showed a strong positive correlation between height and yield among a large population of advanced lines. There is thus gathering support for the use of the $R h t$ genes as a means of exploiting the positive genetical correlations between height and yield. 
Undoubtedly, the move to the semi-dwarf phenotype in wheat has produced a major impact on world agriculture. However, the results presented in this paper and elsewhere indicate clearly the dangers of a too rigid an application of this plant model. As Stoskopf and Fairey (loc. cit.) state " there is a growing awareness that special grain yield problems occur in the progressively shorter-strawed genotypes" of wheat. This paper attempts to provide some of the reasons for these problems and how breeders may seek to overcome them in the future.

Acknoweledgments.-The authors wish to thank Mr E. Simpson, Mrs L. Holt, Mr S. Currell and Miss B. Parker for their help in carrying out this work and Mrs J. E. Brown for her help in the preparation of the manuscript.

\section{REFERENCES}

ALLAN, R. E., VOGEL, O. A., AND PETERSON, J. C. JR. 1968. Inheritance and differentiation of semi-dwarf culm length of wheat. Crop Science, 8, 701-704.

Bingham, J. 1972. Physiological objectives in breeding for grain yield in wheat. Proc. 6th Eucarpia Congress, Cambridge, 1971, 15-29.

Borlaug, N. E. 1968. Wheat breeding and its impact on world food supply. Proc, 3rd Int. Wheat Gene. Symp., Canberra, 1968, I-36.

BRIGGLE, L. W., AND VOGEL, O. A. 1968. Breeding short-statured, disease resistant wheats in the United States. Suppl., Euphytica, 107-130.

BUSCH, R. H., LUCKEN, K. A., AND FROHBERG, R. C. $197 \mathrm{l}$. $\mathrm{F}_{1}$ hybrids versus random $\mathrm{F}_{1}$ line performance and estimates of genetic effects in spring wheat. Crop Science, 11, 357-361.

CAMPBELL, L. G., CASADY, A. J., AND COOK, w. J. 1975. Effects of a single height gene (dw 3) of Sorghum on certain agronomic characters. Crop Science, 15, 595-597.

CASADY, A. J. 1965. Effects of a single height gene $(D W \mathrm{I})$ of Sorghum on grain yield, grain yield components and test weight. Crop Science, 5, 385-388.

CAVALLI, L. L. 1952. An analysis of linkage in quantitative inheritance. Quantitative Inheritance, eds. E. C. Reeve and C. H. Waddington, pp. 135-144. HMSO, London.

CHAUDHry, A. s. 1973. A genetic and cytogenetic study of height in wheat. Ph.D. thesis, Cambridge University.

DONALD, c. M., AND hAMBLIN, J. 1976. Biological yield and harvest index of cereals as agronomic and plant breeding criteria. Adv. Agron., 28, 361-405.

EVANS, L. T., AND WARDLAW, I. F. 1976. Aspects of the comparative physiology of grain yield in cereals. Adv. Agron., 28, 301-350.

FALCONER, D. S. 1961. Introduction to Quantitative Genetics. Oliver and Boyd, Edinburgh and London.

GALE, M. D., AND LAw, C. N. 1977. The identification and exploitation of Norin 10 semidwarfing genes. Plant Breeding Institute Annual Report for 1976, pp. 21-35.

GALE, M. D., LAW, C. N., AND WORLAND, A. J. 1975. The chromosomal location of a major dwarfing gene from Norin 10 in new British semi-dwarf wheats. Heredity, 35, 41 7-421.

GALE, M. D., and MARShALL, G. A. 1976. The chromosomal location of Gai 1 and Rht 1 , genes for gibberellin in sensitivity and semi-dwarfism, in a derivative of Norin 10 wheat. Heredity , 37, 283-289.

hayman, в. I. 1954. The analysis of variance of diallel tables. Biometrics, 10, 235-244.

HERMSEN, J. G. Th. 1963a. The localization of two genes for dwarfing in the wheat variety Timstein by means of substitution lines. Euphytica, 12, 126-129.

HERMSEN, J. G. Th. 1963b. Hybrids necrosis as a problem for the wheat breeder. Euphytica, $12,1-17$.

JINKs, J. L. 1954. The analysis of continuous variation in a diallel cross of Nicotiana rustica varieties. Genetics, 39, 767-788.

JiNks, J. L. 1956. The $\mathrm{F}_{2}$ and backcross generations from a set of diallel crosses. Heredity $10,1-30$.

JINKs, J. L., AND JONEs, R. M. 1958. Estimation of the components of heterosis. Genetics, 43, 223-234.

JOPPA, L. R. 1973. Agronomic characteristics of new-isogenic tall and semi-dwarf lines of durum wheat. Crop Science, 13, 743-746. 
KNOTT, D. R., AND KUMAR, J. 1975. Comparison of early generation yield testing and a single seed descent procedure in wheat breeding. Crop Science, 15, 295-299.

kUSPIRA, J., AND UNRAU, J. 1957. Genetic analysis of certain claaracters in common wheat using whole chromosome substitution lines. Can. 7. Plant Science, 37, 300-326.

LAw, C. N. 1966. Biometrical analysis using chromosome substitutions within a species. In Chromosome Manipulation in Plant Genetics, eds. R. Riley and K. R. Lewis. Suppl., Heredity, 20, 59-85.

LAw, c. N. 1968. European Wheat Aneuploid Co-operative Newsletter, No. 1. (Ed. C. N. Law, published Plant Breeding Institute, Cambridge.)

LAW, C. N., AND WORLAND, A. J. 1973a. Aneuploidy in wheat and its uses in genetic analysis. Plant Breeding Institute Annual Report for 1972, pp. 25-65.

LAW, C. N., AND WORLAND, A. J. 1973b. Chromosome substitutions and their use in the analysis and prediction of wheat varietal performance. Proc. 4th Int. Wheat. Genet. Symp., Missouri, 41-50.

LUPTON, F. G. H. 1975. Dwarf wheats. Spectrum, 135, 9-11.

LUPTON, F. G. H., AND WHitehouse, R. N. H. 1957. Studies on the breeding of self-pollinated cereals. I. Selection methods in breeding for yield. Euphytica, 6, 169-184.

MATHER, к. 1967. Complementary and duplicate gene interactions in biometrical genetics. Heredity, 22, 97-103.

MAther, K., AND jinks, J. L. 1971. Biometrical Genetics, Chapman and Hall Ltd., London. MOORE, K. 1969. The genetical control of the grass-dwarf phenotype in Triticum aestivium L. Euphytica, 18, 190-203

PERKINS, J. M., AND JINKS, J. L. 1970. Detection and estimation of genotype-environmental, linkage and epistatic components of variation for a metrical trial. Heredity, 25, 157-177.

RIGGS, T. J., AND HAYTER, A. M. 1975. A study of the inheritance and inter-relationships of of some agronomically important characters in spring barley. Theoret. Appl. Genet., 46, 257-264.

ROSIELlE, A. A., AND FREY, K. J. 1975. Estimates of selection parameters associated with Harvest Index in oat lines derived from a bulk population. Euphytica, 24, 121-131.

SAMPSON, D. R. 1971. Additive and non-additive genetic variances and genotypic correla tions for yield and other traits in oats. Can. 7. Gen. Cyt., 13, 864-872.

SASAKI, M., MORIYASU, M., MORRIS, R., AND SCHMIDT, J. w. 1968. Chromosomal location of genes for some quantitative characters of wheat using chromosome substitution lines. In Proc. 3rd Int. Wheat Genet. Symp., Canberra, 343-349.

SEARS, E. R. 1953. Nullisomic analysis in common wheat. Am. Nat., 87, 245-252.

SEARs, E. R. 1954. The aneuploids of common wheat. Missour Agric. Exp. Sta. Res. Bull. No. 572 , pp. 59 .

SNAPE, J. W., LAW, C. N., AND WORLAND, A. J. 1977. Whole chromosome analysis of height in wheat. Heredity, 38, 25-36.

STOSKOPF, N. C., AND FAIREY, D. T. 1975. A synchronous tiller maturity - a potential problem in the development of dwarf winter wheat. Plant Breeding Abstracts, 45, 467-472.

UTZ, H. F., ALBER, K. D., SCHNELl, F. W., AND SNOY, M. L. 1973. Selektion in fruhen Generationen des Winterweizens. I. Merkmals korrelatimen. Z. Pflanzenzüchtg, 70, 38-50.

VAN DER VEEN, J. H. 1959. Tests of non-allelic interaction and linkage for quantitative characters in generations derived from two diploid pure lines. Genetica, 30, 201-232.

VOGEL, O. A., ALLAN, R. E., AND PETERSON, c. J. 1963. Plant performance characteristics of semi-dwarf winter wheats producing most efficiently in Eastern Washington. Agron. $\mathcal{F}$., 55, 397-398. 